\title{
COSMOS EVOLUTIVO E PLANO DA CRIAÇÃO NA FILOSOFIA PEIRCEANA*
}

\author{
Lauro Frederico Barbosa da SILVEIRA**
}

\begin{abstract}
RESUMO: O uso da metáfora da sob-existência do plano de um velho fóruin na mente de seu arquiteto, a fim de entender o modo de ser do estado inicial do cosmos poderia dar origem a uma postulação de um plano na mente divina ou na natureza. A perfeição divina e o processo evolucionário do cosmos e da Razão, tais como são expostos na filosofia de PEIRCE, parecem opor-se à realidade de um tal plano. O presente artigo é um ensaio de discussão desta questão.
\end{abstract}

UNITERMOS: Natureza; mente divina; cosmos; razão; evolução; plano; propósito; causação final; causação eficiente; hábito; acaso; amor criativo.

\section{I- Construção arquitetônica e criação cósmica}

Em 1898, no The Logic of Continuity (2. VI.185-213) (a) PEIRCE, a uma certa altura, ao tratar do cosmos no presente estágio de sua evolução, propõe a seguinte comparação:

"Nada mais podemos fazer do que supor que aquelas qualidades sensíveis que agora experimentamos - cores, odores, sentimentos, amores, sofrimentos, surpresas - são somente relíquias de um antigo contínuo de qualidades em ruínas, como um punhado de colunas permanecendo de pé aqui e ali como testemunhas de que aqui algum fórum de um velho mundo, com sua basílica e templos, alguma vez constituiu um grandioso conjunto. E assim como aquele fórum, antes de ser construído, tivera uma vaga sob-existência na mente daquele que planejou sua construção, também o cosmos de qualidades sensíveis, o qual eu desejaria que supusesses, em algum estágio inicial de ser, ter sido tão real quanto tua vida pessoal é neste momento, tenha tido num estágio antecedente de desenvolvimento um ser mais vago, antes que as relações de suas dimensões se tivessem tornado definidas e contraídas.', (2.VI.197)

O texto lido se insere facilmente num conjunto de outros escritos peirceanos que fazem supor um contínuo de sentimentos (feelings) ou de qualidades sensíveis na origem do cosmos, contínuo que sob o aspecto existencial fragmentou-se, embora se mantenha subjacente, como uma realidade (cf. 2., I.167-175, 407-416, 615; VI.132). Este

\footnotetext{
* Este texto é dedicado ao professor IVO ASSAD IBRI, cujas investigações no domínio da Metafísica e da Cosmologia peirceanas suscitaram o presente questionamento e poderão, num breve futuro, of erecer um tratamento muito mais completo deste setor central da filosofia de Charles Sanders PEIRCE.

*: Departamento de Filosofia - Faculdade de Educação, Filosofia, Ciências Sociais e da Documentaçäo - UNESP — 17500-Marília - SP.
} 
contínuo originário e atualmente subjacente à pluralidade dos sentimentos e das qualidades sensíveis, constitui-se, com ef eito, numa suposição fundamental para toda a metafísica peirceana, repercutindo na totalidade de sua filosofia: o contínuo é a forma mais perfeita do geral e é neste que toda a lei e o próprio pensamento encontram sua realidade.

Se esta inserção parece não causar dificuldade, explorar a metáfora que aproxima o cosmos atual das ruínas de um antigo fórum poderia certamente contribuir para a exploração desta importante tese. A própria tese está exigindo que a ela se dedique uma investigação alentada e rigorosa, cuja estratégia não precisaria necessariamente iniciarse com a leitura da comparação em apreço.

A metáfora peirceana, no entanto, parece colocar um problema capaz de gerar interpretações divergentes: o contínuo de qualidades sensíveis suposto, ao menos na origem, por aquelas que agora experimentamos fragmentadas, compara-se, porventura, ao plano mental de quem concebeu a construção do fórum antigo do qual hoje restam apenas ruínas, somente porque, tanto um quanto o outro, realizavam formas de ser menos definidas e contraídas do que as que seus fragmentos hoje apresentam; ou a ambos é também comum, o caráter de concepção presente numa mente produtora? Mais explicitamente: o texto postularia uma mente criadora do cosmos e nesta, a presença do contínuo originário das qualidades sensíveis do qual hoje testemunha a pluralidade heterogênea dos sentimentos; ou não pretende levar a comparação a tais minúcias, deixando em aberto a questão da postulação de uma mente criadora, e, mais ainda, de qualquer entidade semelhante ou comparável a um plano da criação?

A simples leitura do texto não decide definitivamente qual das duas interpretações adotar:

De um lado, o texto restringe-se em afirmar que tanto o cosmos de qualidades sensíveis quanto o fórum antigo apresentavam na origem, modos de ser diversos dos que hoje apresenta o que deles resta. O fórum foi precedido por uma sob-existência na mente de quem o planejou, enquanto o cosmos conheceu... "num estágio antecedente de desenvolvimento um ser mais vago, antes que as relações de suas dimensões se tivessem tornado definidas e contraidas". Os próprios modos de ser originários do cosmos e do fórum não se identificam, salvo em seu caráter menos fatual do que o que apresenta o que deles resta; nenhuma referência, além disto, é feita a uma mente que concebesse o cosmos e que fosse comparada à mente de quem planejou a construção do fórum.

De outro lado, o texto excede em sugestão aos termos explicitamente comparados, abrindo, por conseqüência, um feixe muito maior de cruzamentos entre o que é dito do fórum antigo e o que é dito do cosmos de qualidades sensíveis. Com efeito, para simplesmente apresentar a presença de formas iniciais de ser diferentes das atuais, quer no cosmos, quer na composição arquitetônica, e atribuir àquelas formas uma maior vagueza, não seria necessário recorrer às ruínas do fórum para falar da idéia presente à mente do arquiteto antes da construção do conjunto de edifícios. O recurso à apresentação da construção, outrora organizada mediante a concepção de um planejador, como um punhado de fragmentos, a aproxima muito mais, aliás de modo explícito, do estado atual das qualidades sensíveis. Não parece, pois, fora de propósito perguntar se um estágio concepcional também não caracterizaria o primeiro modo de ser do cosmos antes que, por contração e definição, se diversificasse em fragmentos aparentemente descontínuos. Se na construção do conjunto arquitetônico, uma mente dirigiu a construção antecipando-a idealmente, por que "mutatis mutandis" uma mente criadora não presidiria a efetivação do cosmos, sob a forma de um contínuo perfeito, anterior a qualquer forma reagente, ou mesmo definida? 
SILVEIRA, L.F.B. da - Cosmos evolutivo e plano da criação na filosofia peirceana. Trans/Form/Ação, São Paulo, 8:1-24, 1985.

Mas o próprio texto volta a refrear a extensão de legitimidade da comparação, ao diferenciar nitidamente o estatuto de cada um dos termos implicados. O fórum conhece três momentos em sua existência: um, ao nível ideal e intramental que antecipa e dirige a construção, outro, na plenitude de sua existência quando materializa plenamente a idéia que concebeu e exerce as funções que lhe conferem significação e, um terceiro e último, no qual dele só restam ruínas dispersas a exigir da idéia de quem as observa a conjectura de como teria sido um dia o conjunto e a idéia que orientou sua construção. O cosmos das qualidades sensíveis, porém, só conhece dois estados de ser: um, cuja continuidade não conhecia divisão, diversificação e concreção e outro, em que, em processo crescente, tal variação vai-se produzindo e se determinando em progressivas diferenciações. Num, o processo é presidido plenamente pelo tempo e se constitui ef etivamente na interação entre a mente e a matéria pela determinação da conduta racional do arquiteto. No outro, a anterioridade de um estágio é totalmente inicial e não se submete, portanto, a qualquer contínuo que o preceda ou o presida. Este último caso, como estágio inicial da espontaneidade ainda não diferenciada, assumiria características de um plano de uma concretização posterior mesmo que, por certamente anteceder o próprio tempo, tal concretização não pudesse ser inequivocamente chamada futura? Este plano seria atribuível a uma mente criadora, a uma mente divina? Com constantes cuidados, PEIRCE chega em alguns escritos, e na continuação daquele no qual o texto presentemente em consideração se insere, a admitir que este brotar de idéias num plano de espontaneidade seja designado mente divina (cf. 2. VI.199), mesmo que faça notar que se estaria usando uma linguagem figurada. Designar figurativamente o surgimento inicial como mente divina não parece, no entanto, significar o mesmo que atribuir a esta mente qualquer plano ou conferir a tal estágio inicial do cosmos de qualidades sensíveis qualquer estatuto comparável à antecipação de um estágio futuro de um processo produtivo. Se houver uma mente divina, criadora do cosmos, poder-se-á atribuir ao ato criativo qualquer planejamento, mesmo que realizado eminentemente e, portanto, excluídas as limitações de uma mente intrinsecamente temporal?

\section{2 - Plano da criação: prós e contras}

Somente uma investigação que, embora não se pretenda exaustiva, percorra as passagens nas quais PEIRCE aborda as relações de Deus com o cosmos e do homem com suas obras, poderá trazer subsídios para esclarecer esta questão.

Um conjunto de escritos explicitamente exclue o papel de qualquer mediador nas relações divinas, quer sejam elas interiores à divindade quer se dirijam às criaturas. Não são necessariamente textos que afirmem a realidade divina, pois, antes de tudo, baseiam-se na consideração do que se entende por Deus.

Três textos merecem ser especialmente abordados: um exclui a inteligência divina do domínio de direito da semiótica, outro, caracteriza a relação de criação como uma díada genuína e o último, ao considerar os diversos atributos de Deus, considera que o estatuto atribuível ao conhecimento divino, mais se aproxima do da vontade humana do que de sua faculdade cognitiva.

O primeiro texto (2. II. 227), sobejamente conhecido, data de 1897 e traz a credencial de ser uma exposição formal da natureza e do domínio da semiótica. Depois de estabelecer que cabe a esta ciência, por via abstrativa, determinar... "Como devem ser os caracteres de todos os signos usados por uma inteligência científica”, esclarecendo que por uma inteligência cientifica compreende... "uma inteligência capaz de aprender pela 
experiência', o texto exemplifica o uso de tal abstração e volta a insistir no amplo e geral domínio da ciência que pretende realizar: “... Por tal processo, que no fundo é muito parecido com o raciocínio matemático, podemos tirar conclusões sobre o que seria verdadeiro dos signos em todos os casos, desde que a inteligência que os usasse fosse científica', Segue-se, então, uma única exclusão explícita - e talvez, a única de direito — entre os modos de pensamento relativamente ao que cabe à semiótica abordar: ... “ os modos de pensamento de um Deus, que possuiria uma consciência intuitiva superando a razão, são colocados fora de questão', Um Deus, com efeito, não pode ser considerado uma mente científica. Como nada o ultrapassa, nada ignora e, por conseqüência, nada tem a aprender. Igualmente, nada pode se apresentar a Ele como dotado de qualquer alteridade, pois de algum modo a Ele se acrescentaria, contradizendo sua perfeição: não cabe a um Deus experimentar. Se nada tem a aprender nem a experimentar, um Deus, em seus modos de pensar, não recorre a qualquer mediação e, por conseguinte, a qualquer signo.

O segundo texto (2. I. 326 - 329), datado de 1894, embora aborde a questão do ato da criação divina num exemplo, constitui-se num discurso igualmente formal, de cunho analítico e não manifesta conceder coisa alguma à imprecisão ao escolher o exemplo. Numa tentativa de apresentar, em seus fundamentos, as categorias que denominou cenopitagóricas, o autor explicita a certa altura o estatuto da díada para bem contrapôla à mônada e a tríada e, posteriormente, a ela fazer corresponder a categoria de secundidade. Depois de expor diversos elementos da díada e chamar à atenção propriamente para o caráter diádico de todas as relações que a constituem, dela decorrem e que a caracterizam (cf. 2. I. 326), o texto apresenta um único exemplo, no qual são explicitadas todas as relações anteriormente estabelecidas:

"Como um exemplo de uma díada considere isto: Deus disse, Deixe haver luz, e houve luz.

Não devemos pensar isto como um verso do Gênese, pois o Gênese seria uma terceira coisa. Nem devemos pensá-lo como proposto à nossa aceitação, ou tomado como verdadeiro, pois somos terceiras partes. Devemos simplesmente pensar Deus criando a luz pelo fiat. Não que o fiat e o vir a ser da luz fossem dois fatos, mas que isto se dá num único fato indivisível. Deus e luz são sujeitos. O ato de criação deve ser visto, não como qualquer terceiro objeto mas somente como a talidade (suchness) da conexão entre Deus e a luz. A díada é o fato. Ela determina a existência da luz, e a criatividade de Deus. Os dois aspectos da díada são, primeiro, o de Deus compelindo a existência da luz, e o da luz, por sua vinda à existência, fazendo de Deus um criador. Esta consideração é no presente exemplo meramente um simples ponto de vista, sem nenhuma realidade correspondendo a ele. Este é um dos aspectos especiais do exemplo particular escolhido. Dos dois aspectos da díada, portanto, um é neste caso, fundamental, real, e primário, enquanto que o outro é meramente derivado, formal e secundário.

Escolhi este exemplo porque ele é representado como instantâneo. Houvesse qualquer processo intervindo entre o ato causal e o efeito, ele seria um elemento medial ou terceiro. A terceiridade, no sentido da categoria, é a mesma coisa que mediação. Por essa razão, o diadismo puro é um ato de vontade imediata ou de força cega; pois se houvesse qualquer razão, ou lei, governando-o, ela mediatizaria os dois sujeitos e produziria sua conexão', (2.1.326-327).

$\mathrm{O}$ ato de criação divina é apresentado, pois, como o simples vir a ser da criatura e o ato ordenador de Deus, que poderia ser identificado com seu pensamento, identifica-se 
SILVEIRA, L.F.B. da - Cosmos evolutivo e plano da criação na filosofia peirceana. Trans/Form/Ação, São Paulo, 8:1-24, 1985.

plenamente com a produção, o vir a ser, da criatura. O texto insiste, ao comentar o exemplo, na ausência de qualquer razão ou lei intervindo na criação, e por conseguinte como PEIRCE insiste em mais de uma ocasião, na ausência objetivamente mediadora do próprio tempo.

O que de especial apresenta o exemplo, aquilo no interior da classe das díadas que lhe é genuino, parece ser o que elimina qualquer possibilidade e, muito mais, qualquer exigência de plano. Quando planejamos e resolvemos agir, determinamos nossas ações, determinados pela volição de um objeto cuja ef etivação, enquanto existente, sempre escapa ao nosso domínio, pois sempre é um outro relativamente a nós. Nossa própria conduta escapa, sob algum aspecto, aos nossos planos. No ato criador de um Deus, a relação para com o existente é real pois o ser da criatura é por ele produzido. Como, contudo, nenhum objeto determina a ação divina, se o vir a ser da criatura torna Deus criador, só o torna na demonstração da total dependência da criatura ao criador. A criatura, diferentemente de em qualquer outra díada, não interage com Deus de modo algum, a ele nada acrescenta e, conseqüentemente, não lhe atribui realmente qualquer predicado. Cabe, portanto, dizer que, no ato divino da criação, a criatura não sai de Deus, enquanto que, da parte da criatura, Deus é absolutamente Outro. Salvo numa figuração meramente antropomórfica e certamente obscura, não haveria, pois, razão para se atribuir qualquer plano que presidisse à criação e que, mesmo que só logicamente, a precedesse.

No universo fenomenológico, e ao nível da consciência, é o ato da vontade que caracteriza a díada, pois esta é tensão do sujeito para o objeto e se realiza plenamente na interação ef etiva de ambos (cf. também 2. I. 330-331, 432, 673; V. 129-136). Mesmo que um propósito, como instância mediadora, sempre acompanhe o ato voluntário da mente, sujeita à experiência, a fim de dirigir a conduta ao fim desejado, a consecução da vontade é cega e bruta, pois, em si mesma, não admite mediação alguma e, por conseguinte, a intervenção da razão.

Não parece, pois, ter havido um descuido ou impropriedade do autor, ao apresentar somente a criação como exemplo de díada. Com ef eito, trata-se de um ato especialmente não mediatizado que, transcendendo o fluxo temporal, não o implica em sua realização.

Não há também impropriedade em identificar, após o exemplo, a díada pura ao ato de vontade imediata e à força cega. O que em sua imediatez é, num Deus, intuição produtora, para uma mente capaz de aprender com a experiência é, ou o resultado de mediação, ou a ação dotada de total cegueira.

O risco de atribuir arbitrariedade a Deus, negando-lhe algo como uma instância mediadora ou uma Razão, não impede, no entanto, PEIRCE de, num texto explícito sobre sua concepção do ser perfeito, continuar aproximando a onisciência mais da vontade humana do que do conhecimento. Em 1906, entre as respostas dadas pelo autor sobre sua crença em Deus, figura uma sobre a onisciência divina (2. VI. 508), que confirma a dificuldade em se estabelecer o estatuto de tal atributo, a distância que o separa da racionalidade humana e em conferir sentido a qualquer plano do qual o mundo fenomênico fosse uma decorrência, plano este que se configurasse como a realização de uma mente divina. Ao ser perguntado se cria na onisciência divina, PEIRCE responde:

'Sim, num sentido vago. Com certeza, o conhecimento de Deus é algo completamente diferente do nosso, ao ponto de ser mais parecido com o querer do que com o conhecer. Não creio por que não possamos assumir que Ele se abstém de conhecer demais. Pois esse pensamento é criativo. Mas talvez o caminho mais sá- 
SILVEIRA, L.F.B. da - Cosmos evolutivo e plano da criação na filosofia peirceana. Trans/Form/Ação, São Paulo, 8:1-24, 1985.

bio seja dizer que não sabemos como o pensamento de Deus se realiza e que é simplesmente vão tentar saber. Também não podemos armar qualquer noção sobre o que significa a frase: "o desempenho (ou realização) da Mente Divina. Mesmo a noção mais esmaecida! A questão é tagarelice'”... (2. VI. 508).

Deve-se notar que o texto não só é importante por confirmar o caráter imediato do que se poderia chamar conhecimento divino, pois a vontade é nossa experiência da díada ao nível da consciência, mas por desfazer qualquer pretensão de opor a realidade criada, intrinsicamente contingente, para a qual o futuro é objetivamente indeterminado (cf. 2. VI. 140-142; 1. VIII. 330), ao caráter ilimitado e absolutamente perfeito do conhecimento divino. O conhecimento nada acrescenta a Deus e, deste modo, não constitui limite algum ao criador, que a criação seja limitada. Deus não é ignorante porque o universo criado é finito; ao contrário, a infinitude do conhecimento divino produz, por abundância, o universo criado.

Também, em sua trans-temporalidade, não cabe atribuir a Deus qualquer conhecimento por antecipação daquilo que virá a existir e perguntar se, ou a existência é ilusória ou, se vindo a existir, as coisas criadas não acrescentariam perfeição ao conhecimento divino.

Excluindo da onisciência divina qualquer caráter representativo e antecipatório, PEIRCE prefete, neste texto, afastar como inoportuna uma discussão continuada sobre o modo de pensar de Deus e, sobretudo, a tentativa de prescrutar o mundo como efetivação de um plano, de uma mente divina. Nada impede, porém, que, no freqüente convívio com a racionalidade intrínsica do Universo, da qual, aliás, participa o próprio conhecimento humano, o homem venha a reconhecer a presença criativa do pensamento divino. Para o autor, Deus não é uma negatividade, e isto ele afirma poucos parágrafos antes do texto sobre a onisciência (cf. 2. VI.502). Uma coisa é, contudo, podermos captar um fragmento do pensamento divino no próprio cosmos e no nosso próprio pensamento, outra, e esta sim sendo denunciada como tagarelice, é pretender conceber qualquer pensamento divino, conferindo-lhe, mesmo que implicitamente, um modo de ser semelhante ao humano.

Uma carta de PEIRCE, datada de 1905 e endereçada a o filósofo pragmatista italiano Mario Calderoni, além de agradecer três números de uma revista filosófica italiana que lhe tinham sido ofertados, tem o cuidado de, sumariamente, caracterizar o pragmaticismo reforçando o nível conceitual, geral, em que pretende determinar a conduta humana, evitando reduzir-lhe à determinação da ação. Aborda de momento sucinto, o que é apresentado em What Pragmatism is (2. V. 411-437) e amplamente discutido em Issues of Pragmaticism (2. V. 438-463) e em A Survey of Pragmaticism (2. V. 464-496) e critica, pois, uma posição que, por volta de 1878 adotara por exemplo, em How to make our Ideas Clear (2. V. 388-410). Naquela época, com ef eito, PEIRCE atribuía à ação um peso decisivo na constituição do significado do signo e de seu interpretante. Na carta em apreço, esta posição criticada é denominada ultra-pragmatista e se aproxima, aos olhos do autor, da postura nominalista, por ele jamais aceita, que polariza o universo real em indivíduos existentes que tudo devem à fatualidade do aqui e agora e em idéias gerais, destinadas tão somente a denominar e classificar tais individualidades. O que a carta insiste é num realismo das idéias, muito bem expresso em Issues of Pragmaticism (2. V . 453), quando diz:

"A doutrina escolástica do realismo... "é usualmente definida como a opinião de que há objetos reais que são gerais entre os quais se encontrando os modos de determinação dos singulares existentes, se, com ef eito, não forem somente estes os 
SILVEIRA, L.F.B. da - Cosmos evolutivo e plano da criação na filosofia peirceana. Trans/Form/Ação, São Paulo, 8:1-24, 1985.

tais objetos. Mas a crença nisto pode dificilmente escapar de ser acompanhada do reconhecimento de que há também vagos reais, e especialmente possibilidades reais. Sendo a possibilidade a negação de uma necessidade, a qual é uma espécie de generalidade, (a primeira) é vaga tal como qualquer outra contradição de um geral. Com ef eito, é a realidade de algumas possibilidade que especialmente o pragmatismo está empenhado em afirmar insistentemente. (b)

Neste contexto, a carta assume uma feição especial por colher uma das razões da realidade dessas possibilidades na capacidade do homem conhecer, sob forma de “leis", regularidades do universo. Reúne, pois, a tese da realidade do conhecimento das leis à da realidade das próprias possibilidades do universo colocando a primeira como sustentáculo experimental da segunda e afirma com todo o vigor:

"O fato que ele (o homem) venha sendo capaz de em algum modo predizer como a natureza agirá, de formular "leis" gerais às quais as ocorrências futuras se conformarão, parece prova indutiva de que o homem realmente penetra em alguma medida nas idéias que governam a criação"' (1. VIII. 212).

A apresentação deste argumento deixava entender uma ampla valorização do mesmo quando propunha que esta capacidade experimentada de previsão dos fenômenos naturais fazia com que o homem se vislumbrasse dotado de... "co-entendimento com Deus ou com a Natureza"' (1. VIII. 212). Este dimensionamento da capacidade do conhecimento humano confere-lhe dimensões tão grandes que já o projetam no mundo da figuração, onde seria possível predicar entendimento a Deus e à Natureza, apesar do estatuto claramente humano que a tradição filosófica atribui a tal faculdade. Pode-se, contudo, dizer que a proposta aqui colocada não ultrapassa necessariamente o que se encontra aceito no texto anteriormente comentado (cf. 2. VI. 508), em que se nega discutir o cosmos como realização da mente divina mas se aceita que o conhecimento e o cosmos encontram sua consistência exatamente como criaturas de um pensamento infinitamente perfeito.

Exposto o argumento, a reflexão que dele decorre não tem como deixar de surpreender o leitor que acompanhou a reiterada exclusão de qualquer mediação no ato criador e, por conseqüência, de qualquer idéia que o antecipasse, mesmo que logicamente, e o presidisse. PEIRCE, depois de julgar que a predição científica é prova indutiva de uma presença de ideais governando a criação, dá um passo além e não vê como é possível negar-se não só que a criação seja, em seu ser, da ordem do pensamento - o que, pelo que foi dito de Deus, não necessitaria visar fins que de algum modo a antecipassem - mas que seja dotada.

... “de algum propósito ideal”'. ( some ideal purpose). (1. VIII. 212)

\section{3 - O significado de propósito}

Percorrendo a obra peirceana disponível nos Collected Papers, percebe-se claramente que propósito encontra seu uso próprio no interior do estatuto da inteligência “científica" e, talvez, mais especialmente da inteligência humana. Em 1902, no $A$ detailed classification of Sciences (2. I. 203-283), o autor preocupa-se em distingüir clara e explicitamente o propósito da causa final. A causa final tem um domínio muito mais amplo do que o propósito, sendo que este constitui... "meramente aquela forma de causa final que é a mais familiar à nossa experiência”' (2. I. 211). O destino, por exemplo, é concebido como uma causa final operando sem ter se constituído no propósito de qualquer mente, e a doutrina da evolução não exige que a determinação das causas 
SILVEIRA, L.F.B. da - Cosmos evolutivo e plano da criação na filosofia peirceana. Trans/Form/Ação, São Paulo, 8:1-24, 1985.

e, portanto, do processo do crescimento, que sempre é visto como um processo mental e finalista, decorra do destino ou decorra da providência (cf. 2. I. 204). Se o propósito parece ter lugar onde se impõe a distinção entre o desejo geral e a vontade particularizante, exatamente como um desejo operativo (cf. 2. I. 205), ele parece atribuir-se a mentes dimensionadas no tempo e que representam seus fins para autocontroladamente alcançá-los (cf. também 1. VIII. 272). O que o cosmos evolucionário exige para se ef etivar na organização crescente que o define, é a presença de duas causas cujo modo de operar é reciprocamente inverso: a causa final e a causa eficiente. Enquanto esta última atualiza-o pela força, a primeira, muito mais genuína, faz derivar o próprio cosmos de uma idéia, antecipa o todo às partes, cabendo à causa eficiente a composição ef etiva - e, de algum modo, defectiva - do todo pela ação recíproca das partes (cf. 2. I. 211-220).

Deve-se notar que a distinção estabelecida entre causalidade final e propósito, se esclarece que nem toda causa final prende-se a um propósito, continua no entando insistindo que ela pertence à esfera da mente e imprime aos fenômenos que são por ela governados a marca do universo psíquico e ideal (cf. 2. I. 269). O texto também ajuda a distinguir mente em geral de mente humana e mesmo de toda mente vinculada à temporalidade e à experiência. A noção de idéia parece ser passível de distinção semelhante (cf. 2. I. 220, 227, 269).

Se a forma de causação final com a qual estamos mais familiarizados é o propósito, certamente, é por aproximação a ele que em sua mais ampla dimensão, conseguimos reconhecê-la no Universo. Dadas as dificuldades de compreensão dos textos peirceanos lidos até o momento, esta consideração não pode escapar à atenção e, com ef eito, sua importância é confirmada quando, quase ao término do desenvolvimento da distinção entre causação final e propósito, a semelhança entre ambos é admitida para certamente melhor ressaltar sua não identidade..." a seleção natural é a teoria de como as formas tornam-se adaptativas, isto é, passam a ser governadas por um quasi propósito" (2. I. 269, o grifo é do autor).

Outros textos insistem explicita ou implicitamente em que a causação final não se reduz pura e simplesmente ao propósito, em que este é atribuível às inteligências "científicas" e não à mente em geral e em que o modo de proceder da mente humana, ou razão, difere necessariamente, devido à mediação dos signos da qual depende para orientar a conduta para o futuro em busca de fins, de uma força racional que, por ventura, seja a natureza.

Num dos textos que comporiam o Minute Logic, do mesmo ano de 1902, e que se encontra recolhido nos Collected Papers (2. II. 86), PEIRCE afirma que para uma inteligência temporalmente determinada, o futuro influencia o presente pela causação final, a qual dá origem a um processo evolutivo através de formas mediadoras. Mostra, em seguida, que é deste modo que conhecemos as leis da natureza e que a teoria da seleção natural afirma que a natureza procede na adaptação das formas vivas ao meio mutante. Faz notar que, por este procedimento, tanto a razão humana quanto a natureza atingem seus fins com admirável sucesso, embora ambos não estejam livres de erros e fracassos.

Só duas alternativas poderiam justificar racionalmente esta tendência ao acerto: a existência de uma Razão ordenadora da Razão e da Natureza ou o resultado obtido da própria experiência de conjecturar. Deixando para outra ocasião a consideração desta última alternativa, a qual também aqui será objeto de consideração posterior, volta-se o texto para a hipótese da presença de uma Razão ordenadora universal e sustenta, pela 
SILVEIRA, L.F.B. da - Cosmos evolutivo e plano da criação na filosofia peirceana. Trans/Form/Ação, São Paulo, 8: 1-24, 1985.

exposição exemplificada do raciocínio experimental, que tanto este último, quanto ela não podem operar do mesmo modo. O raciocínio experimental sempre procede pela mediação de um terceiro - a predição, enquanto que uma Razão que regulasse harmonicamente a própria Razão e a Natureza, infere-se, não comportaria qualquer intermediário.

Ainda um texto que comporia também o Minute Logic e que integra atualmente o Philosophy of Mind dos Collected Papers (1. VII. 362-387) reafirma o caráter restritivo do propósito diante da causa final, assim como da consciência face à mente. Propósito e consciência decorrem das limitações que a potencialidade imprime a certas espécies, enquanto que mente e, sobretudo, causa final, realizam-se num universo muito mais geral e irrestrito. Embora o conjunto do texto discuta principalmente o objeto da psicologia como ciência e cuide mais da distinção entre mente e consciência, interessa em especial à consideração presente a passagem que relaciona termo a termo causa final - propósito e mente - consciência. Assim, deste texto, pode-se ler:

“Os psicologistas dizem que a consciência é o atributo essencial da mente, e que o propósito é somente uma modificação especial. Eu sustento que o propósito, ou melhor, a causa final, da qual o propósito é a modificação consciente, é o tema essencial dos próprios estudos dos psicologistas, e que a consciência é um acompanhamento especial da mente, e não universal' (1. VII. 366).

Em termos formais parece, pois, insustentável atribuir propósito à criação e, por conseqüência, um plano que antecipasse sua forma ideal. No estatuto do homem, já seria necessário distinguir aspectos que ultrapassam os limites definitórios ao menos do primeiro conceito e, certamente, também do outro.

Os textos que conferem plano e propósito à criação ou à produção do cosmos não encontrariam qualquer justificativa, não fosse a importância que assumem para a experiência e formação conceitual humana, ambas as noções. As hipóteses não são meras construções nacionais, mas representações de possíveis determinações de conduta. Respondem conjecturalmente a dúvidas verdadeiras experimentadas por quem as formula. Mais de um texto peirceano insiste nesta dimensão irredutivelmente humana da ciência que produzimos e redime os inevitáveis abusos de linguagem presentes nas explicações que damos de realidades que transcendem o domínio da produção humana. O texto em torno do qual toda a presente discussão se realiza, o uso já mencionado da designação mente divina como autora do plano da natureza e a passagem que atribui ao processo constante de adaptação das formas naturais ao meio circundante um quasi propósito, testemunham este viés necessário das representações produzidas pelo homem.

Em 1905, num manuscrito que recebeu do editor dos Collected Papers o título de Consequences of Critical Commom - Sensism (2. V. 502-537), PEIRCE, localizando sua filosofia no interior das tendências vigentes no momento, refuta aceitá-la como um Humanismo mas concorda que pudesse reconhecê-la como um Antropomorfismo. Reconhecer-lhe tal caráter decorreria exatamente do fato de o autor julgar impossível que uma teoria, produto da mente humana, pudesse de todo abandonar as características essenciais de quem a produz. Tratando em especial da questão da causalidade, PEIRCE então afirma aquilo que, como um fundamento geral, é capaz de iluminar a investigação que agora se está fazendo:

“Eu sustento, por exemplo, que o homem está tão completamente encerrado nos 
SILVEIRA, L.F.B. da - Cosmos evolutivo e plano da criação na filosofia peirceana. Trans/Form/Ação, São Paulo, 8:1-24, 1985.

limites de sua experiência prática possível, que sua mente está tão restrita a ser o instrumento de suas necessidades, que ele não pode, em última instância, atribuir significado (mean) a qualquer coisa que transcenda aqueles limites... Por (esta) mesma razão, não creio que o homem possa ter a idéia de qualquer causa ou agente tão estupendos que haja um meio mais adequado de concebê-los do que como vagamente semelhantes ao homem. Portanto, quem quer que possa olhar o céu estrelado sem pensar de que todo este universo deva ter tido uma causa adequada, não pode em minha opinião pensar diferentemente sua causa com um mínimo de justeza do que pensando ser ela Deus"' (2. V. 536).

Em 1908, no A Neglected Argument for the Reality of God, o procedimento de atribuir a Deus um predicado humano que lhe é inadequado, por que a não atribuição poderia induzir a uma maior falsidade ao fazer entender que a Deus caberia o contraditório do predicado, é adotado em decorrência da necessidade humana de representar a realidade através dos conceitos que primariamente são atribuídos ao homem. Este texto assume aqui uma importância excepcional pois o autor se vê na necessidade de atribuir propósito a Deus, só para não apresentá-lo desproposital, privado de propósito:

“... um propósito essencialmente envolve crescimento, e portanto não pode ser atribuído a Deus. Mesmo assim, de acordo com a hipótese (ela mesma, evolutiva) será menos falso atribuir propósito a Deus do que representá-lo sem propósito’’ (2. VI. 466).

Poder-se-ia, no entanto, perguntar por que recorrer a um tal artifício se a não atribuição de um determinado predicado - sobretudo no caso de este ser irremediavelmente inadequado ao sujeito da atribuição - no máximo manteria o conceito do sujeito um pouco mais vago. Na doutrina pragmaticista, no entanto, urge à inteligência lançar mão de todos os recursos nacionais, não para simplesmente guarnecer o sujeito com mais qualidades, mas para, pela predicação, determinar a conduta humana.

A vagueza sempre estará presente nos conceitos (cf. 2. V. 448n), mas a produção das idéias interpretantes como programas gerais de conduta em vista de um fim último de máxima clareza e generalidade não pode recuar diante da contingência de usar um predicado esclarecedor mesmo que o mesmo exija outros que corrijam sua própria ambigüidade. A ciência que a mente humana produz traz invencivelmente a marca do antropomorfismo, não somente porque é produto desta mente mas porque tem na determinação da conduta humana seu próprio objetivo. Pode assim, PEIRCE, em 1903, na resenha do livro de C. A. STRONG - Why the Mind has a Body afirmar:

..." o pragmatismo mantém que não há qualquer outra concepção da realidade que possa ser sustentada do que a concepção de que deva finalmente aparecer para responder aos propósitos humanos, nos quais "humano" significa pertencer à comunhão da humanidade. Ele sustenta que alguém que pense crer que alguma coisa é real para além dos propósitos humanos, na realidade, meramente crê ser verdadeiro para os propósitos humanos que alguma coisa é real para além do propósito humano - , o que talvez possa ser bastante verdadeiro no único sentido que pode ter, a saber, que assim é para os propósitos humanos", (1. VIII. 186). 
SILVEIRA, L.F.B. da - Cosmos evolutivo e plano da criação na filosofia peirceana. Trans/Form/Ação, São Paulo, 8:1-24, 1985.

\section{4 - O amor criativo e a trans-temporalidade de Deus}

A abordagem, no entanto, das relações de Deus com o universo criado não se reduz de modo algum, na obra peirceana, à exigência canhestra de atribuir plano, propósito ou mesmo mente a um ser que, dada sua perfeição, só pode receber equivocamente tais predicados. Não custa reafirmar que Deus, pela definição aceita plenamente por PEIR$\mathrm{CE}$, não se aperfeiçoa em nada pelo ato da criação e transcende totalmente à contingência temporal em suas relações com universo. O tempo, vale lembrar, é uma criatura, caso o universo seja criado.

Textos peirceanos que especificamente tratam da relação criadora de Deus face ao mundo e à humanidade, acentuam seu caráter eminentemente amoroso. Embora sucintamente, convém recorrer a alguns deles para perceber o tratamento conferido ao tema. Em Evolutionary Love, de 1893, (2. VI. 287-317) alguns parágrafos, sobretudo, explicitam este amor criativo. O amor é um desejo concreto de desabrochamento do amado. Quando quem ama é a criatura perfectível, no ato de amor está implicada também a procura do aperfeiçoamento de quem ama, uma vez que o amor se concretizará numa busca comum de fins e implicará alguma interação entre quem ama e quem é amado. Qualquer ato, no ser perfectível, é um aumento de perfeição. Em Deus, no entanto, o amor tudo produz no amado, aí incluído o próprio ser e nada pode reverter, como um acréscimo, a quem ama. Assim, pode-se ler no texto:

... "O auto-amor não é amor; de modo que se o ser próprio de Deus é amor, aquilo que ele ama deve ser carente de amor; assim como uma luminária só pode iluminar o que de outra forma estaria escuro. Henry James, o Swedenborgiano, diz: não há dúvida que é um amor toleravelmente finito ou característico da criatura amar a si mesma no outro, amar o outro por sua conformidade a si mesma: mas nada pode estar em mais flagrante contraste com o Amor criativo, cuja ternura toda ex vi termini deve ser reservada somente para o mais amargamente hostil e negativo a si mesmo, do que este auto-amor' (2. VI. 287).

Nos parágrafos seguintes deste texto, encontram-se três considerações sobre o amor que tomam sua máxima expressão naquele que Deus dedica às criaturas.

Primeiro, afirma-se que o caráter dinâmico do amor permite que, através dele, se compreenda todos os graus de especificidade e espontaneidade presentes no cosmos e dando conta, simultaneamente, da unidade intrinsecamente ordenada da criação como totalidade:

"'O movimento do amor é circular, num mesmo e só impulso projetando criações na independência e levando-as à harmonia'” (2. VI, 288).

Em seguida propõem-se que as leis intrínsecas de desenvolvimento do Universo, às quais em alguns momentos PEIRCE chega a reconhecer como as únicas necessárias para fundamentar metafisicamente a evolução, o crescimento da regularidade ao mesmo tempo que a diversificação crescente e generalizante, (cf. 2. VI. 101; 1. VII. 215-216) encontrem no amor criativo do qual a criação é objeto, sua justificativa primeira. $\mathrm{O}$ amor é doação ao próximo como ensina a mensagem evangélica, sendo total, geral e concreto: 
SILVEIRA, L.F.B. da - Cosmos evolutivo e plano da criação na filosofia peirceana. Trans/Form/Ação, São Paulo, 8: 1-24, 1985.

... “sacrifique sua própria perfeição para o aperfeiçoamento de seu vizinho"' (2. VI. 288)

Ao nível da criação, quando o que é dado é o próprio ser, pode-se traduzir o processo evolutivo universal num desdobrar-se e num consolidar-se crescente desta af etividade e desta recíproca doação:

... "o crescimento somente vem do amor a partir não do auto-sacrifício mas do impulso ardente de preencher o mais alto impulso do outro”' (2. VI. 289)

Finalmente, não dando aqui a ênfase que o texto peirceano confere à questão da permissão e da sustentação do mal e que já se pode perceber na primeira citação acima recolhida do Evolutionary Love (cf. 2. V I. 287), cabe salientar a atribuição ao amor criativo do princípio do desenvolvimento da mente e do próprio cosmos.

Lê-se, deste modo, a seguinte passagem:

"A filosofia que retiramos do evangelho de João é que este é o caminho pelo qual a mente se desenvolve, e a respeito do cosmos, só enquanto ele também é mente, e deste modo tem vida, é ele capaz de evolução posterior', (2. VI. 289).

Em Consequences of Critical Common-Sensism, 1905, ao próprio filósofo cientista - o pragmaticista - , em cuja postura PEIRCE se reconhece, é atribuído um ideal supremo que, para o espanto de todos, constitui-se no poder. Ora, pela explicitação de que espécie de poder se trata, chega-se, guardados os limites que necessariamente se impõem à ação humana, a uma realidade com os mesmos predicados do amor criativo, com que Deus cria o cosmos e com o qual este último evolutivamente cresce em harmonia. O poder que o pragmatismo pretende alcançar não constitui um mero trabalho especulativo nem, muito menos, o atendimento na prática de necessidades particulares. Trata-se da realização conjugada do conhecimento e do amor:

... "o poder criativo da racionalidade, que subjuga todas as outras forças, e legisla sobre elas com seu cetro, o conhecimento, e com seu globo, o amor' (2. V. 520).

Por esse ideal, certamente representado por formas muito diversas, teriam orientado suas vidas os grandes sábios e numerosos homens e mulheres que se dedicaram plenamente aos rejeitados pela sociedade. A sensibilidade do filósofo permite descobrir em exemplos envoltos em misticismo, senão em superstição, quando não em desprezo, não uma manifestação de dimensões sobrenaturais ou reações redutíveis ao psiquismo individual e suas motivações mais ou menos dissimuladas, mas uma surpreendente suposição de uma motivação racional e afetiva. Todos esses homens creriam profundamente, cada um a seu modo, na força viva do amor que não só uniria os homens entre si mas daria coesão ao próprio cosmos e os faria compartilhar da esfera do divino.

Ergue-se aí um realismo que atribui dimensões de ef etiva realidade às relações que unem o universo num único todo, que enfoca sob um único ponto de vista matéria e mente, que reconhece a um tempo, e com dimensões reciprocamente implicadas, lei e acaso. 
SILVEIRA, L.F.B. da - Cosmos evolutivo e plano da criação na filosofia peirceana. Trans/Form/Ação, São Paulo, 8:1-24, 1985.

Esta postura, constituída em doutrina filosófica, é a que o pragmaticismo pretende tomar e ele a reconhece na ciência e na sabedoria. Reconhece também que tal realismo só pode se sustentar se reconhecer que todas as relações do cosmos se fazem sob a égide do amor criativo.

Em 1906, em Answers to questions concerning my belief in God, PEIRCE após considerar a capacidade preditiva da ciência sobre o curso da natureza in futuro, como a capacidade de captarmos um fragmento do pensamento divino, questão cuja possível inteligilidade o presente artigo já teve a oportunidade de investigar, PEIRCE encaminha sobre esse Deus a questão de sua realidade, e nela encontra, não só o fundamento da crença científica, como também da opção dos sábios e dos homens dedicados aos serviços mais sacrificados e exigentes da mais irrestrita doação:

..."a questão se realmente há um tal ser é a questão se toda a ciência física é me-
ramente a ficção - a ficção arbitrária - dos estudantes da natureza, e, mais ain-
da, se a lição única de Gautama Buda, Confúcio, Sócrates e de todos que de qual-
quer ponto de vista tiveram seus caminhos de conduta determinados pela media-
ção sobre o universo psico-físico, é somente sua noção arbitrária ou é a verdade
através das aparências a respeito cia qual o homem frívolo não pensa; e se a cora-
gem sobre-humana que tal contemplação conferiu a padres que vão passar suas
vidas com leprosos e recusam todas as ofertas de resgate é mero fanatismo idiota,
a paixão de um bebê, ou se é a força derivada do poder da verdade"' (2. VI. 503).

A investigação teórica para a verificação da realidade desse Deus parece ao autor, dando prosseguimento ao texto desta última citação, no mínimo insuficiente. O que se procura é encontrado sobretudo nas dimensões af etivas da racionalidade, e seu processo de fixação da crença, neste caso, precede ao argumentativo propriamente dito. Não se trata de modo algum - e isto a obra de PEIRCE desde seus primeiros escritos deixa absolutamente claro (cf. 2. V. 213, 263, 264-317, 358-387) de se procurar na esfera da intuição transcendendo a verdade sobre a realidade divina, pois uma tal faculdade repugna, em sua imediatez, o estatuto de uma inteligência “científica". É no fundamento último da racionalidade, no instinto, primeira inferência que dá origem a todos os posteriores argumentos e que compartilha do modo de ser da própria paixão pela verdade, que o filósofo cientista encontrará o sustentáculo da crença na racionalidade do cosmos (cf. 2. VI. 503).

Encontrar no amor criativo a relação fundamental da produção do universo e do móvel de seu próprio crescimento, amplia a noção de racional a tal ponto que, se o próprio homem não mais se encontra escravo das representações e cindido entre paixão e razão; pensamento e vontade; corpo e mente, muito menos exigirá que se atribua a um criador, formas de representação tais como planos de ação ou propósitos.

Por outro lado, queira-se ou não, plano e propósito supõem alguma dimensão temporal. Planeja-se e propõe-se agir quando o estatuto do ser in futuro impõe-se de algum modo à mente, sendo esta considerada como inteligência e vontade. Cabe atribuir plano e propósito a um ser que, de algum modo, é receptivo e aperfeiçoável, ao mesmo tempo que pode determinar sua conduta. Não custa, por conseqüência, insistir na total transcendência de um possível criador do cosmos face a qualquer relação temporal.

Existem textos claros de PEIRCE sobre este tema, os quais serão vistos a seguir, reservando-se ainda para um momento posterior, a consideração da própria precedência dos estágios iniciais do universo à formação do tempo como contínuo objetivo. 
SILVEIRA, L.F.B. da - Cosmos evolutivo e plano da criação na filosofia peirceana. Trans/Form/Ação, São Paulo, 8:1-24, 1985.

No The Essence of Reasoning, de 1893 (2. IV. 67), ao se discutir a tradicional questão da compatibilidade entre a onisciência divina e a liberdade eficaz do homem, ou até mais amplamente, a real autonomia da natureza, explicita-se plenamente a posição do autor quanto à transcendência divina relativamente ao tempo e à plena objetividade do tempo no universo fenomênico. Deus é criador do tempo como o é do resto do cosmos e, conseqüentemente, não está submisso a seu fluxo. E, tendo ainda o cuidado de criticar a atribuição de saber a Deus, pois saber é mediação e o objeto de um saber é necessariamente dotado de alteridade, recusa qualquer impasse entre a onisciência divina, transtemporal, e a liberdade humana, que diz respeito às relações de decisão diante do futuro indeterminado. Na crítica da atribuição dos conceitos de plano e propósito e, portanto, de previsão a Deus, o texto é claríssimo, pois conclui sua posição nos seguintes termos:

..."Uma previsão literal é certamente contraditória com uma liberdade literal. Mas se dissermos que embora Deus saiba (usando a palavra saber num sentido transliteral) ele nunca soube, não sabe ou nunca saberá, então seu conhecimento de modo algum interfere na liberdade"' (2. IV. 67).

Em 1906, em mais uma passagem de Answers concerning my belief in God, ao ser perguntado se cria que Deus, o ser supremo, tivesse sido o criador do universo, PEIRCE recorre à transcendência divina face ao tempo para recusar delimitar num passado, e mais ainda, num passado definido, a criação. $O$ ato divino não depende do tempo e, tal como Deus, não conhece, em si, começo, processo e fim. A transcendência do ato divino parece a PEIRCE ser melhor representada pela continuidade genuína, a forma a que tendem o pensamento e as regularidades da natureza. Se tal continuidade é expressa no texto em termos temporais, isto se deve à contingência da linguagem humana e, para isso, o leitor é devidamente advertido no texto (cf. 2. VI. 505-506).

\section{5 - A lei universal da aquisição de hábitos}

O cosmos evolutivo, constantemente produzido e dinamizado pelo amor criativo, não necessita ser plasmado por leis diferentes daquela que a própria evolução produz: $a$ lei da aquisição do hábito.

Múltiplos textos peirceanos desenvolvem o conceito de hábito e atribuem tal propriedade tanto à mente quanto à matéria. Uma mera amostragem no conjunto da obra de filósofo pode levantar as principais características deste conceito e das luzes que traz para inteligir a lógica interna da formação contínua do cosmos em todos os seus componentes. Não se pretendendo aqui explorar o hábito como é colhido por PEIRCE na tradição escolástica, nem mesmo no modo como o autor o vê presente na teoria evolucionista de Lamarck, à qual dedica grande respeito (cf. 2. I. 103, VI. 300-301), deve-se acentuar que sua aquisição é, desde textos de 1890, como A Guess at the Riddle (2. I. 400-416), o motivo pelo qual o universo vai progressivamente se organizando desde um conjectural estado de completa indeterminação até um término de absoluta regularidade. Toda a lei e toda a estabilidade decorreria deste único princípio: a tendência da aproximação e da permanência progressivamente reforçada do que é semelhante e do distanciamento, igualmente crescente, do que é dotado de traços de dissemelhança. Fato, tempo, espaço e substância, ao lado de todas as outras formas de regularidade e de continuidade, poderiam decorrer deste único princípio na hipótese cosmológica, de dimensões metafísicas, proposta por PEIRCE (cf. 2. I. 409-416). 
SILVEIRA, L.F.B. da - Cosmos evolutivo e plano da criação na filosofia peirceana. Trans/Form/Ação, São Paulo, 8:1-24, 1985.

Em Architecture of Theories, de 1891 (2. I. 7-34) no decorrer de sua argumentação, o autor salienta a diferença radical entre as leis físicas da mecânica e a lei do hábito: as leis físicas supõem somente as forças e os pontos de aplicação e podem ser calculadas em suas resultantes pelo paralelograma de forças. Os ef eitos produzidos e, dada a reversibilidade da direção de seus componentes, também as causas, são absolutamente previsíveis. Contrariamente às leis físicas, a lei do hábito, lei mental, exige o acaso e a indeterminação presentes para se ef etivar. Seus ef eitos são irreversíveis, envolvem crescimento e, por isso mesmo, repudiam a estrita necessidade. Assim, lê-se no texto:

... "a conformidade exata (do ef eito à causa) estaria em conflito manifesto com a lei; pois ela cristalizaria instantaneamente o pensamento e impediria qualquer formação posterior do hábito"' (2. VI. 23).

Novamente é a afinidade, a semelhança entre os elementos, que fundamenta a lei do hábito e, se ele domina o universo do pensamento, discretamente mostra o texto o que era proposto na hipótese cosmológica do texto do ano anterior: (a lei do hábito) "parece, pois, com as forças não-conservativas da física, tais como a viscosidade e outras semelhantes, que são devidas a uniformidades estatísticas no encontro casual de trilhões de moléculas" (2. VI. 23). Subjacentes às leis da mecânica estão fenômenos que implicam o acaso, sugerindo experimentalmente que o mundo físico possa adquirir progressivamente hábitos e conhecer, com o domínio psíquico, um processo evolutivo.

O Man's Glassy Essence, de 1892, (2. VI. 238-271) discute, em determinado momento, aspectos físicos e psíquicos da estrutura da matéria. Trata-se de uma elabora¿ão hipotética, cientificamente sumária, que visa, no entanto, defender a tese sempre reiterada da unidade de princípio do cosmos. Algumas noções aí encontradas ajudam a pensar o texto fundamental do presente questionamento: a aquisição de hábitos e suas quebras no interior de um cosmos de qualidades sensiveis. Em primeiro lugar, para tratar sumariamente o texto, deve-se notar a atribuição da estabilidade do mundo físico, representada e presumida pelas leis da mecânica, à aquisição de hábitos. Somente esta pode explicar a manutenção de trilhões de moléculas agregadas entre si e mantendo, por conseqüência, propriedades estáveis (2. VI. 262). Se há aquisição de hábitos, uma potencialidade positiva para dar-lhes origem e desenvolvê-los é pressuposta, o que, na terminologia peirceana, corresponde à presença de sentimentos (feelings). Se a matéria se estabilizou e se mantém estável através da aquisição de hábitos e por força deles, ela tem na sua origem potencialidades para tanto, a saber: qualidades de sentimento.

$\mathrm{O}$ caso mais notório, no entanto, de tais propriedades e que, em sua visão unificadora, leva PEIRCE a desenvolver a hipótese da unidade psico-física do cosmos, é o da substância constitutiva da célula dos seres vivos: na terminologia da época, o protoplasma. Trata-se, aos olhos do autor, - que, convém lembrar, era formado em química -, tão-somente de um composto químico, sintetizável em laboratório desde que as condições técnicas se tornassem disponíveis. Tal composto, no entanto, é dotado de sentimento (feeling) como experiências permitem observar; e assim o será, caso seja produzido artificialmente.

As propriedades psíquicas são, pois, atribuíveis à matéria, e não podem ser meramente deduzidas das leis da mecânica. Seria, pois, mais adequado para explicar tal atribuição, admitir que:

..."as ocorrências físicas são somente formas degradadas de ocorrências psíquicas" (2. VI. 264). 
SILVEIRA, L.F.B. da - Cosmos evolutivo e plano da criação na filosofia peirceana. Trans/Form/Ação, São Paulo, 8:1-24, 1985.

Aceitar a hipótese é insistir na extensão universal da aquisição de hábitos, a matéria correspondendo ao resultado final da influência de hábitos, ou disposições crescentemente estáveis, sobre a mente.

A matéria e a mente, tais como podem ser observadas no estágio atual do Universo, somente salientariam os ef eitos característicos do hábito e do acaso, momentos concorrentes e complementares de uma mesma realidade.

A estabilidade e a homogeneidade resultam do hábito atualizador de qualidades potencialmente presentes no caos original, enquanto que a espontaneidade positiva, a variação e a heterogeneidade testemunham a presença constante e insurgente de acaso, que só seria dominado quando nenhuma mudança pudesse mais ocorrer no cosmos.

Matéria e mente são constituídas pela tendência à aquisição de hábitos e pela erupção constante do acaso. No momento atual da evolução do universo, o hábito já exerce na matéria seu poder estabilizador de modo nitidamente predominante, em quanto que, na mente, o acaso ainda se faz notar mais intensamente, mantendo uma margem de indeterminação, transformações e crescimento bastante significativa (cf. 2. V I. 264-267).

Contra todo necessitarismo, das filosofias postuladoras do transcendental ao materialismo mecanicista, a concepção peirceana propõe a constituição do cosmos como uma unidade psíquica da qual as formas mentais e materiais são infinitas realizações evolutivas. Tais realizações são devidas ao princípio constitutivo da afeição e à lei da aquisição de hábitos. Mediante este princípio e esta lei, regularidades vão se impondo diante do acaso, de modo mais ou menos eficaz e definitivo.

O acaso é o elemento de espontaneidade que permanece ativo e que permite que ainda haja novidade no universo. O hábito nada mais é do que a fixação de determinadas formas de conduta em detrimento de uma total variação espontânea. Ao contrário de qualquer exaltação do domínio da “lei”, quer de ordem transcendental, quer de ordem mecânica, PEIRCE louva o estado flexível e inacabado da mente humana, domínio bastante equilibrado no momento evolutivo em que se encontra entre o hábito e a espontaneidade, entre a lei e o acaso.

Assim, em The Law of Mind, escrito também em 1892, pode-se ler as seguintes considerações a respeito da especificidade do modo de sujeição da mente à lei:

..."a incerteza da lei mental não é um mero defeito dela, mas ao contrário, é de sua essência. A verdade é que a mente não está sujeita à "lei” no mesmo sentido rígido que a matéria está. Ela somente experimenta forças suaves que a tornam mais tendentes a agir de um dado modo que de outro. Sempre permanece uma certa porção de espontaneidade arbitrária em sua ação, sem a qual morreria."' (2. VI. 148).

Para terminar esta reconstituição do conceito de hábito no pensamento peirceano, para a qual recorreu-se a amostra bastante reduzida, parece conveniente ler os escritos do autor para o Baldwin Dictionary de 1902, dada a sistematização com que tratam os conceitos expostos, embora tal leitura possa evitar a retomada desnecessária de aspectos anteriormente abordados.

Num dos textos dos Collected Papers procedentes daquele dicionário (2. VI. 98101), a hipótese da evolução das leis pelo princípio da aquisição de hábitos justifica-se por ser este o recurso que evita a arbitrariedade do surgimento repentino de um conjunto complexo de determinações sobre o mundo.

Somente tomando as leis como hábitos de conduta e a própria lei da aquisição de hábitos como a primeira determinação da conduta, pode-se entender como, da mera 
SILVEIRA, L.F.B. da - Cosmos evolutivo e plano da criação na filosofia peirceana. Trans/Form/Ação, São Paulo, 8:1-24, 1985.

potencialidade, chega-se, progressivamente e de modo cada vez mais generalizado, à regularidade de todas as relações no cosmos (cf. 2. VI. 101).

Como a aquisição progressiva e generalizante de hábitos e a determinação da mente em vista dos fins e da forma máxima de sua perfeição, a extensão da lei da aquisição de hábitos é, não só o elo fundamental de unificação da mente e da matéria, como anteriormente pôde-se constatar, mas o texto agora em consideração aponta que é também a determinação da teleonomia geral do Universo, pela qual

... "a causação final é a única primária.",

Ao hábito, porém, não corresponde tão somente a determinação tendencial da conduta pelo fim. Generalizando ações passadas pela representação das mesmas, é também a presença da uniformidade ef etiva do Universo, a relação inversa do acaso. Por esta ef etividade, o hábito atualiza-se na ação do sujeito e confere forma, identidade e permanência a este sujeito. Sob este segundo aspecto, que colhe toda sua inteligibilidade do primeiro, o hábito exerce também causação ef iciente.

Tendendo primeiramente ao fim e procurando aos poucos sua forma, o cosmos, pela lei da aquisição de hábitos, de permanente só mantém esta tendência. Quanto ao resto, tudo lhe é diverso a cada instante, na medida que o hábito em processo de constante aquisição, está sempre mudando sua orientação e sua própria atualização.

Se todas as outras leis verificáveis no universo forem expressões desta tendência primordial, também elas constantemente modificar-se-ão, o acaso as atravessando a cada instante com a introdução do elemento novidade. Desta novidade, aliás, alimentar-se-á o hábito que, por seu lado, ao conferir uniformidade crescente aos elementos cósmicos, tende a anulá-la.

Da complementaridade constante entre hábito e acaso, entre uniformidade e desvio espontâneo da lei, vê PEIRCE o universo avançar em sua forma. O confronto da tendência à ordem com o rompimento da mesma resulta, por um processo naturalmente seletivo, não na volta ao caos original nem num precipitar-se acelerado na rigidez de uma necessidade absoluta, mas no estabelecimento de uma "heterogeneidade organizada”, ou, como prefere o autor, em “uma variedade racionalizada' (2.VI.101).

\section{6- O fim adequado à Razão}

Um cosmos dotado de finalidade, de natureza fundamentalmente psíquica e que se constitui evolutivamente, banhado no acaso, pela lei geral da aquisição de hábitos, informa-se a si mesmo, produz seu próprio fim e não necessita de uma consciência que o dirija em seu todo.

Por ventura, seria ainda exigida uma mente divina, um plano orientador da natureza, mesmo que a proposição de tais presenças sustentando o destino do universo significasse correr o risco de uma séria impropriedade de linguagem? Caberia, sobretudo, identificar esse plano com o cosmos de qualidades sensíveis, plenamente incontrastado num passado infinitamente distante, mas subjacente em sua continuidade em todo o decorrer posterior da evolução, embora em nossos dias só se manifestando fragmentariamente?

A esta altura, é de se crer, que semelhantes questões cada vez menos esperem encontrar uma resposta plenamente afirmativa.

A quantidade de textos peirceanos que insistem em reconhecer a presença de tais entidades no processo contínuo da criação não permite, todavia, que a investigação cesse no presente momento. Deve-se, ao menos, obter um último esclarecimento: o que a 
SILVEIRA, L.F.B. da - Cosmos evolutivo e plano da criação na filosofia peirceana. Trans/Form/Ação, São Paulo, 8:1-24, 1985.

mente humana, no parecer do filósofo, exigiria como seu fim adequado, como o estatuto da perfeição a que tende a alcançar?

Textos que se referem ao tipo de ideal que movimenta a alma de qualquer homem sincero e meditativo e que o leva ao reconhecimento da realidade de Deus insistem que é pela via da beleza que tal processo se fará. Várias passagens do $A$ Neglected Argument for the Reality of God, tanto as que datam de 1908 quanto as que datam de 1910, testemunham este viés da argumentação: a meditação poética promoverá uma crescente disposição de mente a encontrar a realidade divina, tanto no universo das simples idéias, quanto no dos fatos e das coisas, quanto ainda no das mediações sígnicas. Isto se dará, diz um momento do texto:

..."devido a sua beleza, seu fornecimento de um ideal de vida e sua explicação completamente satisfatória de seu tríplice ambiente' (a saber, este tríplice universo, aqui mencionado) (cf. 2. VI. 455, 465).

Pouco mais adiante, no mesmo escrito, PEIRCE dizendo de sua própria experiência e da de outros, insiste que a meditação poética perseguida com plena honestidade científica sobre o tríplice universo, fará com que qualquer homem chegue:

..."a ser movido até as profundezas de sua natureza pela beleza da idéia (da realidade de Deus) e por sua augusta praticabilidade, ao ponto de honestamante amar e adorar seu Deus estritamente hipotético, e de desejar acima de todas as coisas moldar o conjunto total da vida e tudo que brota da ação em conformidade com aquela hipótese.', (2. VI. 467).

A variante de 1910 do argumento negligenciado sobre a realidade de Deus, também chamado argumento humilde, apresenta como um dos principais caminhos para aceitar a realidade de Deus, colher

..." o fruto natural da livre meditação, uma vez que todo coração ficará encantado pela beleza e a adorabilidade da Idéia (da Realidade de Deus), quando ela é desta maneira procurada"' (2. VI. 487).

Na passagem de Answers concerning my belief in God, de 1906, quando ao autor é perguntado se crê que Deus seja infalivel, embora não pareça aqui conveniente desenvolver todas as implicações do texto, e sobretudo como o autor vê a distinção entre a falibilidade e o pecado, e de como evita ocupar-se de teologia propriamente dita, faz ele a seguinte afirmação que merecerá, se bem que brevemente, algum comentário:

..." não creio entender qualquer coisa a respeito disto, mas parece-me que o próprio sentido da palavra "Deus" implica, não com certeza "moralidade", pois Ele me parece estar acima de toda auto-restrição ou lei, mas (implica) perfeição espiritual estética', (2. VI. 510).

O que é aqui excluído de Deus, como Ens Necessarium (cf. 2. VI.452, 465, 489), é a dupla implicação contida na idéia de lei: Deus como ser que desconhece qualquer contingência, não experimenta nada e, por conseqüência, numa segunda ordem, não generaliza para o futuro os limites impostos por tal experiência; não antecipa situações ex- 
SILVEIRA, L.F.B. da - Cosmos evolutivo e plano da criação na filosofia peirceana. Trans/Form/Ação, São Paulo, 8:1-24, 1985.

perimentais e não se submete à representação e à sua forma de expressão: a lei. Deus, por definição e em decorrência do raciocínio aqui apresentado, não é constrangido a adotar critérios de ação, pois nem sequer necessita procurar fins em busca dos quais agiria. Não cabe, portanto, atribuir "moralidade" a Deus.

Embora sendo o Ens Necessarium, por não ser contingente, Deus não está submisso a qualquer necessidade ou imposição. A ordem de sua perfeição seria mais adequadamente encontrável no âmbito do puramente admirável ou, como diz o texto, na ..."perf eição espiritual estética'.

Para melhor entender esta perfeição, convém verificar como é possível encontrar na ordem do que fenomenologicamente é representativo da espontaneidade e da potencialidade positiva, - primeira instância de um processo que, se não é superativo, é, no mínimo, mais desenvolvido e realizador da experiência de uma inteligência científicaa esfera onde se localizariam as mais adequadas atribuições de Deus.

O texto dos Ideals of Conduct, especialmente em seus últimos parágrafos (2. I. 612 615), decorrente das Lowell Lectures de 1903, dedica-se ao esclarecimento de como atribuir como finalidade última de conduta humana, e da Razão em geral, um objeto esteticamente ideal. As exigências de perfeição cobradas deste objeto para que esteja à altura da razão humana, constituirão necessariamente as mínimas condições para que seja possível buscar predicados atribuíveis a Deus e ao Universo.

$\mathrm{Na}$ busca do objeto que possa corresponder à finalidade última da conduta humana, PEIRCE chega à consideração clássica de encontrá-la na beleza, sendo que tal proposta sai da boca do esteta, quando o lógico e o estudioso de ética já não tinham conseguido, cada um em seu domínio, encontrar uma solução convincente. Se, no entanto, o belo se encontrar ao nível do deleite, tomando este como uma qualidade de sentimento, o áutor não admite, salvo se uma prova verdadeiramente convicente for apresentada, que..." qualquer qualidade particular de sentimento seja admirável sem uma razão" (2. I. 612).

Avançando o texto, PEIRCE aprofunda a consideração do que pode corresponder ao fim último do homem e, sem desprezar seu caráter estético, insiste exatamente na propriedade da admirabilidade, irredutível à utilidade, e afirma que

..."o objeto admirável, que é admirável per se deve, sem dúvida, ser geral”.

Prejudicada está, pois, a proposta do deleite como qualidade sensível, pois esta é particular. Também não poderá identificar-se com o fim último porque sua particularidade mesma a faz uma entre múltiplas outras qualidades e o fim, sobretudo o fim último, deverá constituir-se num único ideal, já que

... “a unidade é essencial a toda idéia e a todo ideal”, (2. I. 613).

Se um sentimento particular não pode constituir-se no admirável per se, também este admirável não poderá encontrar-se na gratificação de um desejo. O que impossibilita ao filósofo aceitar tal objeto é a incomparavelmente mais alta dignidade e perfeição do amor e da razão, dos dois elementos que como acima foi visto, compõem o amor criativo e a força que o filósofo pragmaticista procura antes de tudo, e que constituem reconhecidamente os modos mais altos da consciência humana. Do mesmo modo, o Universo da Natureza ao qual o homem reverencia com esses seus dois mais altos atribu- 
SILVEIRA, L.F.B. da - Cosmos evolutivo e plano da criação na filosofia peirceana. Trans/Form/Ação, São Paulo, 8:1-24, 1985.

tos, seria vilipendiado se fosse assumido como voltado tão somente ao atendimento de um desejo da ordem do sentimento (cf. 2. I. 614).

O quadro referencial em que questões clássicas, como é a que constitui o objeto de discussão no texto, necessita para assumir inteligibilidade plena para os homens contemporâneos do autor considerar a Razão no estatuto atual de seu desenvolvimento e em suas relações com um meio que também se transforma. Os acontecimentos políticos, religiosos e científicos da história ocidental, desde o período do Renascimento, manifestam e reforçam mudanças tão profundas na consciência das exigências de autonomia e especificidade da investigação racional e do caráter experimental da produção da verdade e das diversas leis que a representam no universo, que não é suportável e convincente atribuir algo estático como fim último da Razão e esperar que nesse ideal a ela possa encontrar seu máximo prazer.

Se se quiser procurar o admirável per seno período da história em que PEIRCE elabora seu pensamento, deve-se esperar que ele corresponda a essas exigências de liberdade para a satisfação das quais, luta ardorosamente a Razão. Diz assim o texto:

..." nestes dias, eu digo, quando estas idéias de progresso e crescimento cresceram elas mesmas ao ponto de ocuparem nossas mentes tanto quanto fazem agora, como é possível esperar de nós que permitamos que passe a suposição de que o admirável em si mesmo seja qualquer resultado estacionário?', (2. VI. 614).

As mentes mais avançadas não admitem, há tempo, que a Razão se submeta a prescrições fixadas previamente. A Razão atual só pode encontrar um ideal que plenamente a realize, pode-se dizer em conformidade com a teoria peirceana do amor criativo e da aquisição universal de hábitos, num processo evolutivo geral do qual nada fica à margem, e que toma a própria Razão em seu desenvolver. No íntimo da Razão, nesse processo plenamente adequado aos seus mais altos modos de consciência que é o fenômeno essencialmente psíquico do crescimento e da evolução, é que, tudo indica, PEIRCE é capaz de identificar uma forma originária de espontaneidade que dirija a Razão a um fim tão infinito quanto sua própria potencialidade. Tal forma originária poderia se apresentar como uma qualidade de sentimento. Nada porém que integre a Razão pode ser excluído de seu aperfeiçoar-se e da busca do fim que lhe é adequado. Não cabe também inverter o grau de perfeição dos diversos aspectos da Razão e submeter o amor e o conhecimento às emoções e as qualidades de sentimento (cf. 2. VI. 614).

Elaborar hipoteticamente o que pode ser o fim adequado da Razão, seu ideal de conduta, sem prejudicar a integridade dinâmica evolucionária que a constitui, é o trabalho desenvolvido no final de texto.

Primeiro, cabe conceituar com a máxima clareza e atenção o que se deve entender por Razão para interrogar sobre o que para ela pode ser a perfeição última; depois, deve-se analisar sua conduta em busca da plenitude.

A Razão não seria aqui a faculdade humana manifestando-se na mente, na história do desenvolvimento da mente e na natureza, e constituindo-se, conseqüentemente, numa realização particular. Trata-se, outrossim, do que nela se manifesta como exatamente rompendo a particularidade de cada uma de suas corporificações. Os conceitos por mais comuns que sejam, tais como o das qualidades adjetivas dos objetos sensíveis, revelam seu caráter objetivamente geral quando, embora só experimentados existencialmente, são previsões para o futuro do comportamento das classes de substâncias das quais são predicados. Ora, conceitos são atos de pensamento, manifestações inequívocas da Razão. 
SILVEIRA, L.F.B. da - Cosmos evolutivo e plano da criação na filosofia peirceana. Trans/Form/Ação, São Paulo, 8:1-24, 1985.

"O verdadeiro ser do Geral, da Razão, adverte PEIRCE, é de tal natureza que este ser consiste (o grifo é do autor) na Razão governar de fato os acontecimentos", (2. I. 615).

Não há, pois, incompatibilidade entre o caráter eminentemente geral da Razão e sua necessária corporificação. Não se trata mais uma vez, poder-se-ia dizer, de qualquer oposição entre espiritual e material e entre abstrato e concreto.

No geral se encontram as classes dos fenômenos experimentais, compartilhando plenamente, independentemente de suas essências particulares, do caráter psíquico, geral e evolutivo que caracteriza a Razão: os fenômenos experimentais, sejam lá quais forem, são da ordem do pensamento e são regidos por suas suaves e flexíveis leis.

$\mathrm{Na}$ atualidade do fatual, por sua vez, encontra-se o lugar de aplicação e ef etivação de toda e qualquer espécie de fenômeno experimental. A Razão existencialmente é um fato submetido à causação eficiente e, por sua vez, a exercendo (cf. 2. I. 615).

Não há, no pensamento peirceano aqui exposto, qualquer motivo para se estabelecer duas classes: uma eidética - embora o termo não seja peirceano e não queira fazer interferir uma tradição que não é a sua - e ideal - este sim, um termo freqüentemente presente nos escritos do autor -, e uma classe material e empírica. Não há separação entre ambas, e os textos sobre o amor criativo e a aquisição de hábitos parecem suficientes para esclarecer a questão; muito menos há oposição metafísica em sua constituição. O Idealismo objetivo de PEIRCE é monista e o princípio universal postulado é o do Psiquismo.

Geral, em sua natureza, e atual e particularizada em sua efetivação, a Razão necessariamente não pode conhecer um modo de ser estático de absoluta aquisição de perfeição. Seu estado, segundo PEIRCE, é de constante incipiência e de crescimento. Nenhum fato a esgota, sempre sendo necessárias mais realizações empíricas para que sua perfeição mais se manifeste. Nenhuma qualidade, de que ordem for, lhe é estranha, pois em sua unidade encontram-se todas elas presentes em infinitas intensidades:

... “inclusive o prazer (que sente) de seu lugar entre o resto” (2.1.615).

De fato, esse prazer se coloca, pois ela é múltipla e uma em sua manifestação, ela cresce num contínuo evolutivo que a torna essencialmente idêntica num contínuo mudar igualmente essencial. A materialidade desta manifestação psíquica exige que a Razão só encontre seu fim adequado, não se reduzindo à instância do sensível, mas no desenvolvimento corporificado e manifestado do Geral (cf. 2. I. 615).

Chega-se, então, a o final do texto, quando o fim adequado a que tende a Razão em busca de sua máxima perfeição, tal como a filosofia peirceana pode hipoteticamente conceber, é primorosamente exposto:

... "A criação do Universo, que não teve lugar durante uma semana ocupada, no ano 4004 a.C., mas está continuando hoje e nunca estará pronta, é o verdadeiro desenvolvimento da Razão. Não posso ver como alguém pode ter um ideal mais satisfatório do admirável do que o desenvolvimento da Razão assim entendido. A única coisa cuja admirabilidade não é devida a uma razão ulterior é a própria Razão compreendida em toda sua plenitude, tão longe quanto nós podemos compreendê-la. Sob esta concepção, o ideal de conduta será executar nossa pequena função na operação da criação, of erecendo uma ajuda para tornar o mundo mais razoável do que nunca, enquanto isto nos couber' (2. I. 615). 
SILVEIRA, L.F.B. da - Cosmos evolutivo e plano da criação na filosofia peirceana. Trans/Form/Ação, São Paulo, 8:1-24, 1985.

Razão e Universo se identificam; a criação contínua e evolutiva é o próprio desenvolvimento da Razão, o qual, por sua vez, constitui o ideal sempre perseguido e sempre alcançado por esta mesma Razão. A evolução do universo é a manifestação que a Razão exige para, pela ef etivação do ideal, alcançá-lo.

Nada mais é procurado, e parece poder-se concluir que, como a nada mais perfeito a Razão aspiraria, de nada mais perfeito ela necessitaria e a nada mais perfeito ela indicaria.

Procurar um Deus além da Razão e, por conseqüência, além do Universo, tornaria sem sentido identificar o desenvolvimento integral da Razão com a

... “única coisa cuja admirabilidade não é devida a uma razão ulterior”.

\section{7 - Deus e auto-suficiência da Razão}

Para se admitir Deus sem prejudicar a integridade da apresentação da Razão nos Ideals of Conduct, somente duas alternativas parecem aceitáveis: ou numa perspectiva de cunho espinosista, Deus é a própria Natureza em sua intensidade, unidade e infinitude ou, como no texto já analisado sobre o estatuto da díada (2. I. 326-329), Deus mantém com o Universo uma relação sui generis, em que toda a determinação só decorre do criador na criatura, enquanto que da criatura ao criador, ao fazê-lo tal, nenhuma relação real se estabeleceria. Deus seria um absolutamente outro para a criatura, não cabendo a esta nem sequer aspirar conhecê-lo.

Esta última alternativa só poderia ser assumida de um ponto de vista totalmente analítico de onde estaria excluído qualquer juízo sobre a realidade de Deus. Com ef eito, é sobre a noção de Deus que o texto se coloca, quando aplica a relação diádica à criação. Este ponto de vista coincide com o do texto que, ao estabelecer o estatuto da semiótica, exclui o pensamento de um Deus de seu domínio, pois este pensamento tem uma imediatez que exclui por definição o aprendizado pela experiência.

Existem os textos que podem ser lidos na primeira alternativa: todos aqueles que identificam mente divina e Natureza, os que atribuem a Deus e ao cosmos, amor criativo e mesmo aqueles que reconhecem que a representação de Deus deveria se fazer no domínio da beleza. Sob este último aspecto, reconhece-se Deus como o admirável per se, semelhante ao fim a que tende a Razão.

Se, por analogia, a determinação temporal da conduta racional humana, atribuir planejamento à produção do cosmos, o texto jamais poderá restringir-se à formalidade de atribuir a Deus esse modo de pensar e de agir. O texto não poderá veicular a segunda alternativa, mas sim a primeira, onde as metáforas com os modos limitados de realização da Razão guardam uma certa legitimidade, muitas vezes compulsória. O texto de The Logic of Continuity ao qual pertence a comparação que deu ensejo a todas estas considerações (cf. 2. VI.197), apresenta, sem dúvida, o tipo menos formal de tratamento e compartilha, portanto, do que está sendo considerado a primeira alternativa. Deste tipo é testemunha a passagem contida logo após o texto em discussão, passagem, aliás, também citada no presente artigo. Nesta, embora reconhecendo a ingenuidade do procedimento, PEIRCE aceita que se atribua figurativamente ao desenvolvimento espontâneo do cosmos, surgir ele da determinação do Criador Divino, e poder mesmo ser chamado mente de Deus (cf. 2. VI.199).

\section{$8-$ A provável extensão da metáfora original}

As considerações de PEIRCE sobre o cosmos e a Razão parecem, no entanto, mui- 
SILVEIRA, L.F.B. da - Cosmos evolutivo e plano da criação na filosofia peirceana. Trans/Form/Ação, São Paulo, 8: 1-24, 1985.

to longe de exigir a extensão da metáfora da sob-existência do plano do fórum na mente de quem o projetou para o esclarecimento do estatuto do cosmos originário de qualidades sensíveis.

Para compreender a evolução do Universo a partir deste estado originário e a exigência da permanência do mesmo para que o Universo se mantenha, certamente não é necessário aproximar tal estado de um plano presente numa mente divina ou no âmago racional da Natureza. O caráter ideal de sua potencialidade não parece exigir que uma interpretação do texto inicial do presente artigo faça tal aproximação ainda mais que, fazê-la, implica em correr o risco de se perder no equívoco uma compreensão da Razão, do Universo e do Homem tão cuidadosamente elaborada.

Se o nível das quạlidades sensíveis e dos sentimentos não pode satisfazer à razão humana como seu fim, mais insuportável parece ser, atribuir à mente divina um cosmos daquele nível, marcado pela potencialidade ainda não atualizada no teatro das reações muito menos, generalizada na forma de pensamento. Que os fatos e as leis suponham o substrato dos sentimentos e não o neguem de modo algum, não os reduz ao modo de ser deste substrato nem significa que constituam níveis mais perfeitos de realização. $\mathrm{O}$ amor criativo, com o qual se identificam a Razão, o cosmos e o Criador, não pode se limitar ao nível do real onde predomina a simples potencialidade por mais rica de possibilidades que ela seja. Se um ideal fosse atribuído ao Criador, este, no mínimo, deveria corresponder ao mais alto grau de realização do cosmos.

Por outro lado, no entanto, se a evolução da Razão e do cosmos for sua própria realidade, e, se por conseqüência, sua perfeição for encontrada no desenvolvimento desta evolução como o único ideal a ser alcançado, não cabe, tenha a forma que tiver, propor um plano divino preestabelecido e, portanto, necessitante para a Razão e o cosmos.

Se a objeção que imediatamente se levantar à denúncia da impropriedade de se propor um plano para a Razão e o cosmos, for a da transtemporalidade da criação divina, diante da qual a novidade e a espontaneidade inerentes à evolução não seriam prejudicados pela presença de um plano de Deus, conviria responder que, descartar o fluxo temporal sem afastar a atribuição de plano ou de propósito a Deus ou à Natureza, não evitaria em nada que se desfigurasse a lei primeira da formação da Razão e do cosmos. O mais inoportuno é, com efeito, postular um plano num processo em que o ideal é produzido no próprio evoluir de sua consecução.

Para manter o máximo respeito ao que há de mais central na filosofia peirceana, cabe, pois, restringir a comparação da evolução do cosmos a partir do contínuo das qualidades sensíveis e permanentemente sustentada nele, com as ruínas de um conjunto monumental antigo somente à aparente fragmentação das qualidades devido à expansão da lei da aquisição de hábitos. Na hipótese peirceana (cf. 2. I. 407-416), o cosmos de qualidades sensíveis apresentava uma distribuição menos selecionada de suas manifestações antes que as regularidades se impuzessem à indeterminação original.

Este domínio incontrastado da espontaneidade lembrava a PEIRCE o plano de um fórum antes de sua construção. Assim como, em nossos dias, deste fórum só sobrariam ruínas, do contínuo originário das qualidades sensíveis só se apresentariam no estágio atual da evolução, formas contraídas e mais definidas como que o dilacerando. Da aproximação da imagem do fórum e da concepção do cosmos, restaria também o reconhecimento em cada um deles, desde seus estágios mais iniciais, de formas diferentes de realidade que teriam conhecido. O conjunto arquitetônico teria existido diferentemente sob a forma de plano e sob a forma de construção se é que não se diferenciaria também 
SILVEIRA, L.F.B. da - Cosmos evolutivo e plano da criação na filosofia peirceana. Trans/Form/Ação, São Paulo, 8: 1-24, 1985.

quando, com o tempo, transformou-se em ruínas. O cosmos da pura espontaneidade viria se transformando em seu modo de ser desde que, pela tendência universal à aquisiçõ de hábitos, passou progressivamente a constituir-se num universo de leis tendendo a generalizar-se cada vez mais em direção ao futuro.

Estas formas de ser e suas transformações, no entanto, nada têm de comum entre si. A simples comparação presente no texto do filósofo não permite, com ef eito, procurar na esfera cósmica o que é especialmente determinado pela contingência da conduta racional humana.

\section{NOTAS}

a - As referências aos textos dos Collected Papers of Charles Sanders Peirce seguem a convenção internacionalmente adotada: o primeiro número remete às Referências Bibliográficas, o segundo número remete ao volume dos Collected Papers e os números que daí se seguem, correspondem à numeração dos parágrafos daquele volume. No caso da referência a uma nota de rodapé dos Collected Papers, segue-se a letra $n$ ao número do parágrafo a que ela está apensa.

b - Para uma exposição minuciosa da noção de idéia vaga e de vagueza de um conceito em PEIRCE, conferir 2. V. 448 e 505.

SILVEIRA, L.F.B. da - Evolutionary Cosmos and plan of creation in the peircean philosophy.

Trans/Form/Ação, São Paulo, 8:1-24, 1985.

ABSTRACT: The use of the metaphor of the under existence of the plan of an old forum in the mind of its architect in order to understand the mode of being of the initial estate of the cosmos could originate a postulation of a plan in the divine mind or in the Nature. The divine perfection and the evolutionary process of the cosmos and Reason, as they are exposed in PEIRCE's philosophy, seam to be opposed to the reality of such a plan. The present paper discusses this question.

KEY-WORDS: Nature; divine mind; cosmos; Reasons; evolution; plan; purpose; final causation; efficient causation; habit; chance; creative love.

\section{REFERÊNCIAS BIBLIOGRÁFICAS}

I. BURKS, A.W., ed. - Collected Papers of Charles Sanders Peirce. Cambridge, Harvard Univ. Press, 1958. v. VII-VIII.
2. HARTSHORNE, C. \& WEISS, R., eds. Collected Papers of Charles Sanders Peirce. 3 th printing. Cambridge, The Belknap Press of Harvard Univ. Press, 1974. v. I-VI. 